\title{
AN IMPACT ON QUALITY RELATED TO WORK LIFE AND ITS EFFECT ON EMPLOYEE PRODUCTIVITY DURING COVID-19
}

\author{
${ }^{1}$ Prof. (Dr.) Narendra Mohan Mishra, ${ }^{2}$ Priyanka Naicker \\ ${ }^{1}$ Professor and Dean Faculty of Management, SRM Institute of Science and Technology \\ Delhi NCR Campus, Ghaziabad-201204 \\ dean.mgmt.ncr@srmist.edu.in,narendrm1@srmist.edu.in \\ ${ }^{2}$ Assistant professor, Management Studies, SRM Institute of Science and Technology Delhi \\ NCR Campus, Ghaziabad-201204,priyankp2@srmist.edu.in
}

\begin{abstract}
:
In highly globalized and competitive society, the work culture of the organization is much stressful due to the requirement of the highest level of performance for the sustenance in the market. The stack- holders (employees, employers, client's customers, and consumers) increase productivity in organization when there is an excessive expectation which takes into the count of professional's physical and mental well-being. Clear-cut of an equitable balance is better in work and life. Productive HR and Operations activities help the employees to work in addition which help them to not abandon their personal life. When there is an optimum productivity, minimum staff turnover, depletion in absenteeism and talent optimization then the organization would be in beneficial. In the Month of December 2019 due to Covid-19 virus attack there was a stressful time on the earth and it paralysed the social and economic development of the Earth. The professionals today are in the Covid-19 ERA. Latterly, Before COVID-19 ERA professionals were extremely well recognized and were in high demand. As there is rapidly new-fangled pandemic situation, Demand and supply chain and Job opportunity has totally collapsed. Individual started living their lives in the big threats.
\end{abstract}

Purpose: To examine employee productivity during Covid 19 associated with the quality related to work life.

Design/Methodology - In a context, a survey method was to analyse the efficacy and the quality related to work life in the COVID-19 which was used to furnish an outline of concept about the work life and its quality to efficacy during the COVID-19 period in India. Employee answered the question related to the productivity of employee and quality of work life and questions pertaining to culture, and different associated dimensions of quality of services.

Finding - The Endowment of work-life program was neither properly implement nor discussed in firms. As far as the employee job satisfaction was concerned, the work-life increases the level of job satisfaction. The endowment of work-life brings the very positive 
changes in the productivity of the firm. A model for $Q W L$ dimensions was proposed in this paper.

Research Limitations/ implementation - The finding is based on the fact provided by the respondent at a specific time window of the study with limited respondent and sample is also convenient in my study and it has been not interpreted as observable.Practical implications Now days the industry is becoming more competitive more ICT managed and technologically -driven and grater employee competence and quality of work culture will be required for many industries to survive.

Keywords: Productivity, covid-19, Employee, Endowment of work life, work culture, Job satisfaction,

Paper Type - Research paper

1. Introduction: The success of business is extremely relying on how it enchants selects, appraised, and develop its workforce. In millennium world the organization has to give more flexibility so that they provide and develop the workforce and relish their commitment. To satisfy the organizational purpose and employee needs the organization need to adopt new strategies which would raise the employees Quality of work life (QWL). This Study is conducted to understand the importance and impact on employee performance and all in all organizational performance during Covid -19 eras which would create a productive work life practices. Hereafter the world will have more women Entrepreneurs and they gone stimulate and take on the QWL program. In a tremendously competitive work environment, the professionals would have pressure not just for performing but for excelling their work also. There is a high expectation from the organization to raise productivity at any cost which effects on the physical and psychological wellbeing of professionals. Human Resource and Operations activities help the employees to work in addition which help them to not abandon their personal life. With the portrait in mind, a detail note on quality of work life during covid 19 and its effect on productivity of employee is summarized on the basis of primary data collection i.e. Questionnaire. This learning aims to furnish the information, suggestions and recommendations for the victorious execution on quality of work life program. An organization can only provide and satisfy its employees with extraordinary growth and to be beneficial. (Lau, 1998). "Now, organizations must design a new model of work for tomorrow, by presenting new approaches for teams to effectively work from home, leveraging technology and innovative ways to increase collaboration, and fostering an environment of inclusion and belonging - to build a more loyal, productive and sustainable workforce." (survey, 2020). Expand social protection policies and enhance basic income and cash transfers based on real-time monitoring and national needs to boost aggregate demand (consumption). COVID 19 has brought a dual shock (supply and demand) requiring stimulation of both economic production and consumption. Vulnerable countries with limited resources need access to international finance. The time for global equity is now, not only as a moral imperative, but as the sole way to avoid a protracted global depression.(Chebly, 2020). 
Quality related to work life: An Individual's wide employment-related experience is Quality related of working life (QWL). It has proposed models of quality related of working life which also attribute to as Quality of work life by various Authors and Researchers. It has large number of factors, so often classified as "motivator factors" supposing to make enrich work experience a high productive one. It has aim to measure quality related of working life with assorted rating scales. The stack holders of business, National economic performance some other publications have also given importance and attention on QWL.

The key components on quality related to working life has a primary external work factors are salary, and working culture and the internal work itself have other aspects which includes:

- Power of Individual

- Decency and Equity

- participation of Employee Management

- Social Favour

- Self-Improvement

- Outcome on extra work activities

- Valid future at work

- Usefulness of present skills of Individual

- Society acceptance of the work or product

It varies according to organization and employee group which relevant the quality of working life concepts (TAYLOR, 1977).

\section{Benefits of Quality of work Life.}

[4] Telecommunicating from home has side effects on the ability of remote workers to handle the interplay between work related commitments and daily life activities. This comes from the overlapping between Life and work, which leads to greater contamination of personal concerns and work duties. Work engagement lessens the perception of work - life unbalance. The increased work related fatigue triggered by remote working may produce a physical and emotional exhaustion of home based teleworkers. (Palumbo.2020).

Quality of work life improves the overall total environment as

1. Economic Benefits: Receiving enough financial income and monetary rewards.

2. Physical Working Condition: At the Job convenience and physical comfort conditions are affecting.

3. Self-Respect: An adult should be treated with Respect and dignity.

4. Supervisory Relationship: There should be mutual understanding with the supervisor

5. Organizational Climate: The Approach and outlook of the organization should be in the interest of worker then only there would be betterment of Industry. 
6. Employee Commitment: Employee should be loyal to the company and would be concerned for its future.

Quality related to work life reduces the stress of the employee. (Swathi, 2016)

With the leadership and Human Resource Literature special attention has attracted because of better Quality of work life. But still lot of work take shape on the outlook of work Satisfaction and mainly on the advocacy preferably than research and few studies has reviewed the quality related to work life from the outlook of Human Resource and most of the studies were done before COVID- 19.

So there is less observable evidence which effect and associated with the learning of the Quality related to work life and its effect on productivity of employee at the time of Covid 19.

In accordance with, the study directed the following research question.

Research Question 1: To what outstretch is Quality related to work Life occurring in the Business.

Research Question 2: Is Quality related to work life firmly associated with the job satisfaction of employees.

Research Question 3: Is Quality related to work life firmly associated with productivity.

Method: Sampling frame consisted of the employee (operational level, managerial level, executive level) at a sample of 31 that admit to participate in the study through online Questionnaire.

Employee answered the questions pertaining to https://forms.gle/9gmXM1NMCaiRQkWN9 varied factors influence on the quality of work life which is mentioned below. It was collected keeping in the view of respondents 3 years need in a 5 - point scale $(5=$ Most preferred and 1 = Least preferred). The different option was provided related to the Quality of work life as Job security, benefit on mental and physical fitness ,flexitime, work and life balance, participative management, recognition, fun at work place, personal growth opportunity, career growth opportunity, fair compensation ,organizational involvement, training opportunity ,supervisory support ,support from peers , Involvement ,stress at work, working condition, job satisfaction, Adequate leave options, and Autonomous work group and response was collected, compiled and visualized .

To this study, employee from different part of India was asked to respond on some specific statement which was related to the core facts as appended in the Table 1:

\begin{tabular}{|l|}
\hline Options: \\
\hline Are any Quality of work life (QWL) programmes conducted in your organization? \\
\hline Quality work life programmes, helped in bringing out change in productivity \\
\hline Do you find any usefulness after attending earlier QWL programs? \\
\hline
\end{tabular}




\begin{tabular}{l} 
According to your which programme should be given more attention. \\
Training program \\
Quality of life program \\
Issue orientated Program \\
Any other \\
\hline What is your suggestion /feedback on QWL programme in general for an organization? \\
Answer: \\
\hline I am satisfied with my Quality of Life \\
\hline
\end{tabular}

In the above table some responses are collected in the 5 Point Likert's Scale and some responses are collected in the text form for further qualitative study.

Measurement pretesting was accomplished through the administration of the Questionnaire to 10 working faculty members of the self- finance Institution during the Covid-19 period Lock down period. Researcher uploaded the questionnaire of the google form and shared the link to all connects through mail, and Facebook. It has also been assured to the respondent that only the researcher can see the individual response.

Multi- item scale configuration and measurement conceptualizations have been supported by the pre- test result. Hence, the researchers proceeded with the main study and collected the data from 31 respondents. Figure 1 identity the profile of respondents:

Figure 1

\begin{tabular}{|c|c|c|c|}
\hline $\begin{array}{l}\text { Gender: } \\
31 \text { responses }\end{array}$ & $\begin{array}{l}\text { Male } \\
\text { Female } \\
\text { Prefer not to say }\end{array}$ & $\begin{array}{l}\text { Designation: } \\
\text { 31 responses }\end{array}$ & 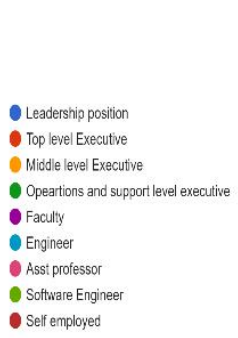 \\
\hline $\begin{array}{l}\text { Experience: } \\
30 \text { responses }\end{array}$ & $\begin{array}{l}\text { 1 } 1 \text { to } 5 \text { years } \\
\text { - } 6 \text { to } 10 \text { years } \\
\text { 10 to } 15 \text { years } \\
\text { - } 16 \text { years and above }\end{array}$ & $\begin{array}{l}\text { Age (In Years): } \\
31 \text { responses }\end{array}$ & $\begin{array}{l}\text { - } 20.22 \text { years } \\
\text { - } 30.39 \\
\text { 40.-49 } \\
\text { - } 50 \text { and Above }\end{array}$ \\
\hline
\end{tabular}


Measures: Relationship between the Quality related to work and productivity of any organization has identified and failed in search of the literature when it empirically tested. Hence, 20 item measures for the work life quality and it were developed based on the indepth interview with the peers and referring to the literatures related to title.

Data Results and Analysis: These sections relate the analyses and directed the questions, parametric and non-parametric test as well as correlation analysis was used for the study findings. To explore the internal consistency it was undertaken by operating the questionnaire to the base, an evaluation on initial base for the quality related to work life and productivity scales. This pre-test data standardized Cronbach $\alpha$ for the Quality related to work-life and productivity scales were $\mathbf{0 . 9 1 2 5 2 9}$.

Coefficient alpha $(\alpha)$ is the most applied estimate of multi-item scale's reliability. Coefficient (Cronbach $\alpha$ ) ranges in value from 0 , meaning no consistency, to 1 , meaning complete consistency. Scales with a $\alpha$ between .80 and .95 are considered to have very good reliability, and a $\alpha$ between .60 and .70 indicates fair reliability. In this study $\alpha$ value is near to .95 , therefore, it was concluded that the scale and level of reliability and validity are highly consistence.

\begin{tabular}{|c|c|c|c|c|c|c|}
\hline ITEM & Mean & $\begin{array}{l}\text { Standard } \\
\text { Deviation }\end{array}$ & $\begin{array}{l}\text { T } \\
\text { value }\end{array}$ & $\begin{array}{l}\text { df(n- } \\
\text { 1) }\end{array}$ & $\begin{array}{l}\text { T } \\
\text { Critic } \\
\text { al }\end{array}$ & $\begin{array}{l}\text { Hypothesis } \\
\text { Mean } \\
\text { mu=3 } \\
\text { (R:Rejecte } \\
\text { d, A: } \\
\text { Excepted) }\end{array}$ \\
\hline $\begin{array}{l}\text { Benefits in my mental and } \\
\text { physical fitness }\end{array}$ & $\begin{array}{l}3.8387 \\
1\end{array}$ & $\begin{array}{l}1.0032206 \\
2\end{array}$ & $\begin{array}{l}4.6547 \\
47\end{array}$ & 30 & 1.697 & $\mathbf{R}$ \\
\hline Job Security & $\begin{array}{l}3.7096 \\
77\end{array}$ & $\begin{array}{l}1.1602743 \\
46\end{array}$ & $\begin{array}{l}3.4055 \\
02\end{array}$ & 30 & 1.697 & $\mathbf{R}$ \\
\hline Flexitime & $\begin{array}{l}4.0645 \\
16\end{array}$ & $\begin{array}{l}0.9638631 \\
95\end{array}$ & $\begin{array}{l}6.1491 \\
87\end{array}$ & 30 & 1.697 & $\mathbf{R}$ \\
\hline Work and life balance & $\begin{array}{l}3.9677 \\
42\end{array}$ & $\begin{array}{l}1.0796255 \\
82\end{array}$ & $\begin{array}{l}4.9907 \\
66\end{array}$ & 30 & 1.697 & $\mathbf{R}$ \\
\hline Participative management & $\begin{array}{l}3.6451 \\
61\end{array}$ & $\begin{array}{l}1.1120068 \\
07\end{array}$ & $\begin{array}{l}3.2302 \\
91\end{array}$ & 30 & 1.697 & $\mathbf{R}$ \\
\hline Recognition & $\begin{array}{l}3.3870 \\
97\end{array}$ & $\begin{array}{l}1.4532129 \\
77\end{array}$ & $\begin{array}{l}1.4831 \\
02\end{array}$ & 30 & 1.697 & $\mathbf{A}$ \\
\hline Fun at workplace & 3 & $\begin{array}{l}1.5705625 \\
32\end{array}$ & $\mathbf{0}$ & 30 & 1.697 & $\mathbf{A}$ \\
\hline $\begin{array}{ll}\text { Personal } & \text { growth } \\
\text { opportunity } & \end{array}$ & $\begin{array}{l}3.7096 \\
77\end{array}$ & $\begin{array}{l}1.2700012 \\
7\end{array}$ & $\begin{array}{l}3.1112 \\
7\end{array}$ & 30 & 1.697 & $\mathbf{R}$ \\
\hline $\begin{array}{ll}\text { Career } & \text { growth } \\
\text { opportunity } & \end{array}$ & $\begin{array}{l}3.5172 \\
41\end{array}$ & $\begin{array}{l}1.5264498 \\
88\end{array}$ & $\begin{array}{l}1.8866 \\
51\end{array}$ & 30 & 1.697 & $\mathbf{R}$ \\
\hline Fair compensation & $\begin{array}{l}3.6451 \\
61\end{array}$ & $\begin{array}{l}1.3303730 \\
58\end{array}$ & $\begin{array}{l}2.7000 \\
74\end{array}$ & 30 & 1.697 & $\mathbf{R}$ \\
\hline
\end{tabular}




\begin{tabular}{|c|c|c|c|c|c|c|}
\hline $\begin{array}{l}\text { Organizational } \\
\text { involvement }\end{array}$ & $\begin{array}{l}3.6451 \\
61\end{array}$ & $\begin{array}{l}1.2792807 \\
12\end{array}$ & $\begin{array}{l}2.8079 \\
11\end{array}$ & 30 & 1.697 & $\mathbf{R}$ \\
\hline Training opportunities & $\begin{array}{l}3.6451 \\
61\end{array}$ & 1.2529535 & $\begin{array}{l}2.8669 \\
11\end{array}$ & 30 & 1.697 & $\mathbf{R}$ \\
\hline Supervisory support & $\begin{array}{l}.4193 \\
55\end{array}$ & $\begin{array}{l}1.3360188 \\
01\end{array}$ & $\begin{array}{l}1.7476 \\
32\end{array}$ & 30 & 1.697 & $\mathbf{R}$ \\
\hline Support from peers & 3.5 & $\begin{array}{l}1.1962585 \\
35\end{array}$ & $\begin{array}{l}2.3271 \\
58\end{array}$ & 30 & 1.697 & $\mathbf{R}$ \\
\hline Involvement & $\begin{array}{l}3.6774 \\
19\end{array}$ & $\begin{array}{l}1.1368698 \\
77\end{array}$ & $\begin{array}{l}3.3176 \\
28\end{array}$ & 30 & 1.697 & $\mathbf{R}$ \\
\hline Stress at work & $\begin{array}{l}3.3225 \\
81\end{array}$ & $\begin{array}{l}1.1071614 \\
39\end{array}$ & $\begin{array}{l}1.6222 \\
14\end{array}$ & 30 & 1.697 & $\mathbf{A}$ \\
\hline Working conditions & $\begin{array}{l}3.9677 \\
42\end{array}$ & $\begin{array}{l}0.9122817 \\
9\end{array}$ & $\begin{array}{l}5.9062 \\
44\end{array}$ & 30 & 1.697 & $\mathbf{R}$ \\
\hline Job satisfaction & $\begin{array}{l}3.6896 \\
55\end{array}$ & $\begin{array}{l}1.2565101 \\
41\end{array}$ & $\begin{array}{l}3.0559 \\
54\end{array}$ & 30 & 1.697 & $\mathbf{R}$ \\
\hline Adequate leave options & $\begin{array}{l}3.9677 \\
42\end{array}$ & $\begin{array}{l}0.9122817 \\
9\end{array}$ & $\begin{array}{l}5.9062 \\
44\end{array}$ & 30 & 1.697 & $\mathbf{R}$ \\
\hline Autonomous work groups & $\begin{array}{l}3.0967 \\
74\end{array}$ & $\begin{array}{l}0.9782582 \\
72\end{array}$ & $\begin{array}{l}0.5507 \\
91\end{array}$ & 30 & 1.697 & $\mathbf{A}$ \\
\hline $\begin{array}{l}\text { Do any Quality related } \\
\text { work life }(Q W L) \\
\text { programmes conducted in } \\
\text { your organization? }\end{array}$ & $\begin{array}{l}3.1612 \\
9\end{array}$ & $\begin{array}{l}1.0032206 \\
2\end{array}$ & $\begin{array}{l}0.8951 \\
44\end{array}$ & 30 & 1.697 & $\mathbf{A}$ \\
\hline $\begin{array}{l}\text { Quality work life } \\
\text { programmes, helped in } \\
\text { bringing out change in } \\
\text { productivity }\end{array}$ & $\begin{array}{l}0.3870 \\
97\end{array}$ & $\begin{array}{l}0.4951376 \\
48\end{array}$ & $\begin{array}{l}- \\
29.381 \\
8\end{array}$ & 30 & 1.697 & $\mathbf{R}$ \\
\hline $\begin{array}{l}\text { Do you find any } \\
\text { usefulness after attending } \\
\text { earlier } \\
\text { QWL }\end{array}$ & $\begin{array}{l}3.3870 \\
97\end{array}$ & $\begin{array}{l}1.1158679 \\
54\end{array}$ & $\begin{array}{l}1.9314 \\
68\end{array}$ & 30 & 1.697 & $\mathbf{R}$ \\
\hline $\begin{array}{l}\text { According to Your which } \\
\text { programme should be } \\
\text { given more attention }\end{array}$ & & & & 30 & 1.697 & $\begin{array}{l}\text { Not } \\
\text { applicable }\end{array}$ \\
\hline $\begin{array}{l}\text { What is your suggestion } \\
\text { /feedback on QWL } \\
\text { programme in general for } \\
\text { an organization? }\end{array}$ & & & & 30 & 1.697 & $\begin{array}{l}\text { Not } \\
\text { applicable }\end{array}$ \\
\hline $\begin{array}{l}\text { I am satisfied with my } \\
\text { Quality of Life }\end{array}$ & 3.16 & 1.003 & $\begin{array}{l}0.8951 \\
44\end{array}$ & 30 & 1.697 & $\mathbf{A}$ \\
\hline
\end{tabular}

Table 2: Hypothesis Testing Analysis Report 
Finding: In the Table 2 the quality of work life was exhibited to perform and access Items mean scores, standard deviations and the result of analysis .Hypothesis related to each of the dimensions have been tested using t-test with the assumption of $95 \%$ confidence level i.e., .05 significance level. The hypotheses mean were considered as 3 which is neutral. In the table 2 the t-test reports clearly indicate the following facts as the $t$-critical is 1.697 at 30 degree of freedom $(\mathrm{df}=\mathrm{n}-1)$ because in this study the sample size $(\mathrm{n})$ is 31 . After comparing each calculated t- value, following findings were observed as the dimensions of the quality related to work-life in the firms are mental and physical fitness, Job security, Flexitime, work-life balance, participation management, personal growth opportunity, carrier growth opportunity, fair compensations, organizational involvement, training opportunity supervisory support, support from peers, working conditions, Job satisfaction, adequate leave options ( because calculated $t$-value> 1.697) .

During the covid-19 lock-down and after lock-down, to check regardless if the quality related to work-life programs was implemented properly, result (t-value $0.8951<1.697$ ) excepted the null hypothesis that the quality related to work-life program was neither properly implement nor discussed. (RQ1). The concerned is the poor quality related to work-life program during Covid-19 was significant.

As far as the employee job satisfaction was concerned (RQ2) the null hypothesis is rejected ( $t$ value 3.0559>1.697), and it was observed that the Quality related to work-life increases the level of work satisfaction.

The calculated t-value for response pertaining to the quality related to work-life helps in brings out change in productivity is 29.381 , which is much higher to the critical t- value of 1.697. Rejects the null hypothesis and the finding is the quality related to work-life bring the very positive changes in productivity of the firm (RQ3).

Numerous other finding related to which programme should be given more attention was visualized in figure 2 .

Figure: 2 Preferences

\section{According to you which programme should be given more attention 32 responses}

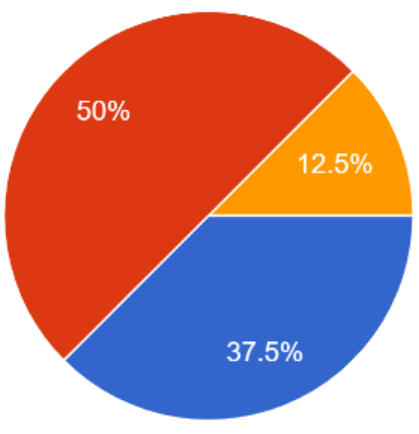

Training program

Quality of life program

Issue orientated Program

Any other 
The 50\% respondent preferred quality of work-life program over other option such as training program, Issue oriented program, and any other.

While collecting the data, respondent suggested and given the feedback as

- No such QWL programme has been conducted in our organisation. The organisation is perception and feeling driven while ignoring the obvious output and efforts of deserving employees.

- It should stress upon physical and emotional wellbeing of employee.

- Must be realistic, not window dressing.

- There should be regular program conducted to improve QWL.

- It should not affect overall performance \& effectiveness of the organisation adversely.

- Should be based on the need of the hour and for employee benefits.

- QWL programs are important for the sense of belongingness and motivation. These should be organized periodically and with interactive format.

- Programme in keeping mind of futuristic challenge's and problems.

- When you are in working from home due to Covid then the balance between work life and personal should be managed.

- I have not attended the QWL session. I would like to attend it and give more valuable feedback.

- Meditation program, some entertainment program

- Should be focused on giving training to employees.

- Dedicate time for each team for the program and make it mandatory within working hours so each employee get benefitted.

From the above discussion it is evident that the respondent is very much concerned and aware about the quality related to work-life and suggesting the way to implement.

\section{Conclusion:}

It is apparent from the conclusion that management most significant contribution in the era of COVID-19 was ensuring the Quality of work-life to their work force of the firm. The industry must start developing a quality framework for work-life around the dimensions which is visualized and developed based on above analysis in Figure 3. 


\section{Figure 3: Quality of work life framework}

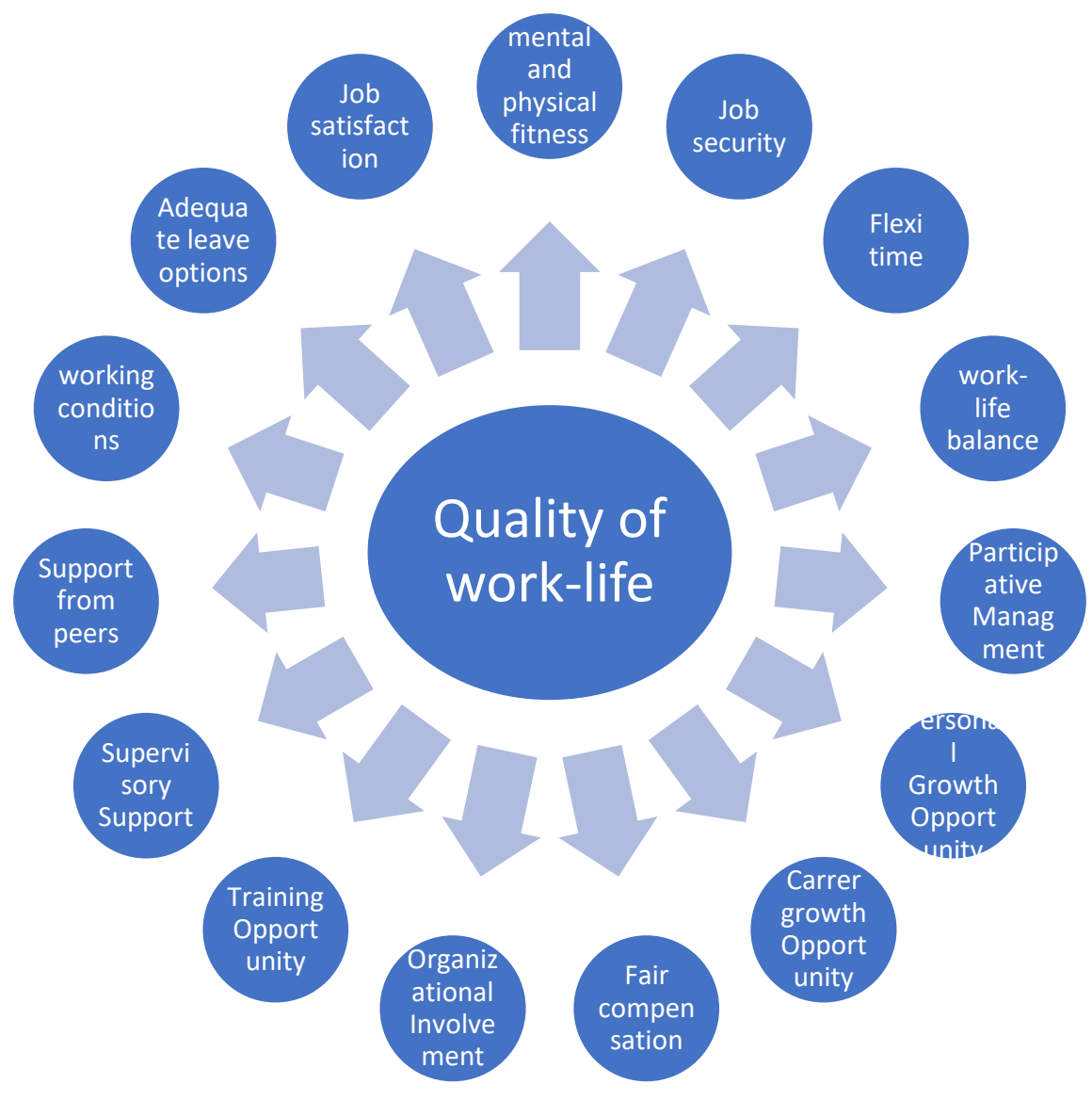

To be in the opinion that the firm wishes to remain productive and competitive by increasable evaluating the feasibility of adopting more quality of work -life with focused approach.

According to this research we may attract the attention towards the senior management to consider and implement the quality of work life in the firm during covid 19

Limitations and Future Research: Almost researcher has a Number of shortcomings which serves as catalyst for upcoming research. The prime study was to hold the idea about quality related to work life of the firm and due to constraint in Time the data size is 31 only therefore the chances of marginal error is $4.35 \%$. The survey tools used is google form, wherein the email id of the respondent was captured with their due permission and the limit to response only one time was enabled but the app was not having the feature to capture the IP address of the respondent. The framework / model for the dimension of the quality related to work life without the weightage are another limitation of this study. However, the research on the topic impact Covid 19 - on the work culture, economy and development and retention of employees / workers which stimulated the Empirical Research. 


\section{Bibliography:}

1. Lau, R. M. (1998). A win-win paradigm for quality of work life and business performance. Human Resource Development Quarterly, 9(3), 211-226. Retrieved from https://search.proquest.com/scholarly-journals/win-paradigm-quality-work-life-bus, 211$\underline{226 .}$

2. KPMG survey: Majority of U.S. employees report improved work experience since onset of COVID-19: Improved productivity, quality of work, and work-life balance received high scores, but opportunities to support employees with mental health and to address racial inequality were revealed. (2020, Aug 19). PR Newswire Retrieved fromhttps://search.proquest.com/wire-feeds/kpmg-survey-majority-u-s-employeesreport/docview/2435142017/se-2?accountid $=145290$

3. Chebly, J., Schiano, A., \& Mehra, D. (2020). The value of work: Rethinking labor productivity in times of COVID-19 and automation. American Journal of Economics and Sociology, 79(4) doi: http://dx.doi.org/10.1111/ajes.12357

4. Palumbo, R. (2020). Let me go to the office! an investigation into the side effects of working from home on work-life balance. The International Journal of Public Sector Management, 33(6), 771-790. doi: http://dx.doi.org/10.1108/IJPSM-06-2020-0150

5. Swathi, V., \& Reddy, M. S. (2016). Implications of stress on quality of work life among teachers: An empirical study. IPE Journal of Management, 6(1), 46-52. Retrieved from https://www.proquest.com/scholarly-journals/implications-stress-on-quality-work-lifeamong/docview/1828144377/se-2?accountid $=145290$

6. Lau, R. S. M., \& May, B. E. (1998). A win-win paradigm for quality of work life and business performance. Human Resource Development Quarterly, 9(3), 211-226. Retrieved from https://search.proquest.com/scholarly-journals/win-paradigm-quality-work-lifebusiness/docview/234903665/se-2? accountid $=145290$

7. TAYLOR, J.C. (1977), Job satisfaction and quality of working life: A reassessment. Journal of Occupational Psychology, 50: 243-252. https://doi.org/10.1111/j.2044$\underline{8325.1977 . t b 00381 .}$ 